\title{
An Observation of Nocturnal Activity in a Central-Italian Asp (Vipera aspis francisciredi)
}

\author{
Riccardo G. Mattea ${ }^{1}$ and Steven J. R. Allain ${ }^{2}$ \\ ${ }^{1}$ Via Guglielmo Oberdan 21, Terni, 05100, Italy (riccardo.mattea@hotmail.it) \\ ${ }^{2} 11$ Trafalgar Way, Braintree, Essex, CM7 9UX, UK (steveallain@live.co.uk)
}

$\mathrm{R}$ oads can have major effects on wildlife that include mortality, changes in behaviour, habitat degradation and fragmentation, various forms of pollution, and the formation of anthropological barriers (Dinetti 2000; Shine et al. 2004). Reptiles and amphibians are particularly susceptible to road mortality; for example, a study conducted in southwestern Poland reported 190 dead Grass Snakes (Natrix natrix) in just 10 months of data collection on a 1,800-m stretch of road (Ciesiołkiewicz et al. 2006).

The Central Italian Asp (Vipera aspis francisciredi) is a sturdy, medium-sized viper that can reach lengths of about $60 \mathrm{~cm}$ (Speybroeck et al. 2016). These snakes, which are the most commonly encountered and widely distributed venomous species on the Italian Peninsula (Fiacchini 2009), exploit a wide range of habitats that include rocky hillsides, mountains (to elevations of about 3,000 m), scrubland, and other xeric situations (Speybroeck et al. 2016). The Central Italian Asp is diurnal throughout most of the year, hunting prey such as birds, small mammals, and lizards (Speybroeck et al. 2016).

Throughout their range, road-killed asp vipers are encountered regularly (Meek 2009). At 2130 h on 12 October 2018, RGM found a female $V$. a. francisciredi dead on the road (Fig. 1) in Colli sul Velino, Lazio (ca. $250 \mathrm{~m}$ asl). Central-Italian
Asps have been found to be active until $1840 \mathrm{~h}$ (Meek 2013), leading us to believe that this is the latest record of activity reported for this species. Although the carcass could have been there for hours, RGM noticed that some muscles were still twitching, suggesting that the animal was a very recent kill.

The area in question is dominated by agricultural land and deciduous mixed woodlands with many bodies of water creating a habitat mosaic. The climate is temperate, with hot, humid summers and cold winters. In recent years, warmer temperatures have been recorded in the peninsula even during autumn; on the day of our observation the maximum temperature was $24^{\circ} \mathrm{C}$ and the minimum $10^{\circ} \mathrm{C}$ with no precipitation (3Bmeteo 2019). Snakes move in order to find food, potential mates, to thermoregulate, or to reach an area of suitable habitat, a refuge, or a hibernaculum (Madsen 1984; Meek 2013, 2015, 2016; Rugiero et al. 2018). The relatively high temperature could explain why the snake was still active during the evening. However, movements typically take place during the day when a snake can more readily thermoregulate. Changes in climate might be affecting the activity and behavior of these snakes across Europe (Luiselli et al. 2018) and more research is desperately needed to understand the effects of climatic change on $V$. aspis.

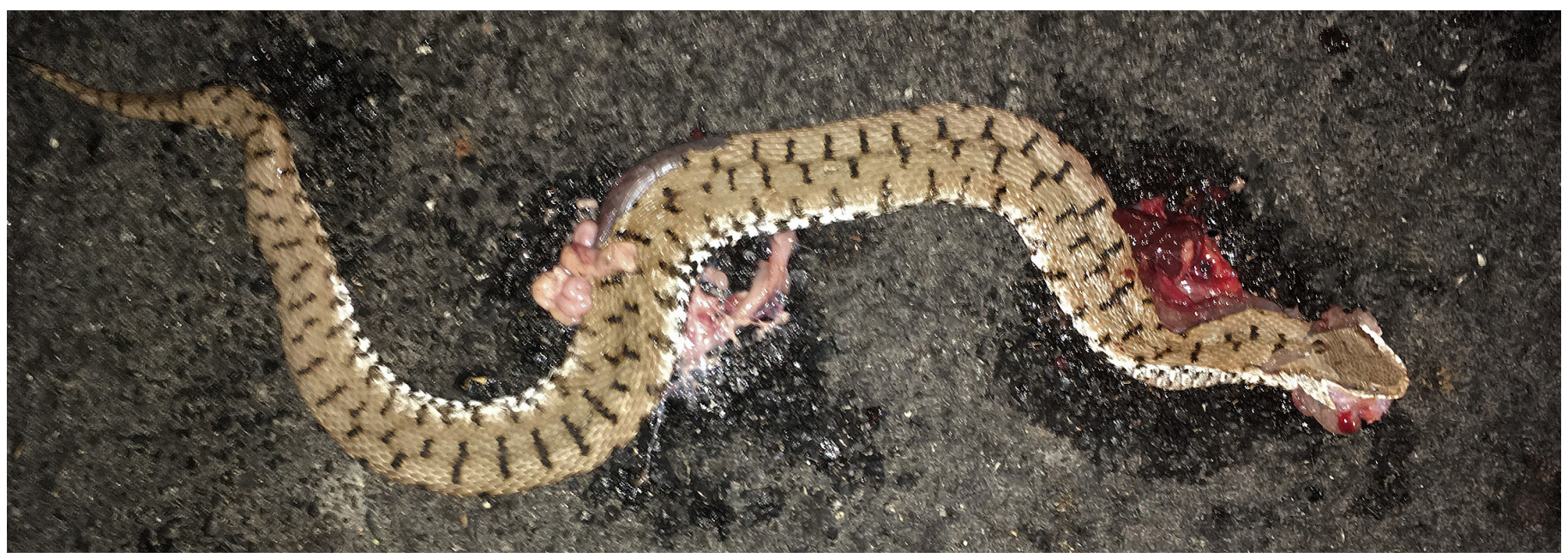

Fig. 1. A Central-Italian Asp (Vipera aspis francisciredi) found dead on the road in Colli sul Velino, Umbria, Italy. Photograph by Riccardo G. Mattea. 


\section{Literature Cited}

3Bmeteo. 2019. Storico Colli Sul Velino. <https://www.3bmeteo.com/meteo/ colli+sul+velino/storico/201810>.

Ciesiołkiewicz, J., G. Orłowski, and A. El anowski. 2006. High juvenile mortality of grass snakes Natrix natrix (L.) on a suburban road. Polish Journal of Ecology 54: 465-472.

Dinetti, M. 2000. Infrastrutture ecologiche. Manuale pratico per progettare e costruire le opera urbane nel rispetto della conservazione della biodiversità. Il Verde Editoriale, Milano, Italy.

Fiacchini, D. 2010. Anfibi e rettili del Parco Nazionale dei Monti Sibillini: risultati della prima campagna di censimento (2006-2009). In: L. Di Tizio, A.R. Di Cerbo, N. Di Francesco, and A. Cameli (eds.), Atti VIII Congresso Nazionale Societas Herpetologica Italica (Chieti, 22-26 settembre 2010), Ianieri Edizioni, Pescara, Italy.

Luiselli, L., L. Vignoli, L. Rugiero, and R. Meek. 2018. Declining occupancy rates in the hibernacula of aspic vipers (Vipera aspis) in Italy and France; evidence for climatic effects? Herpetological Journal 28: 137-142.

Madsen, T. 1984. Movements, home range size and habitat use of radio-tracked grass snakes (Natrix natrix) in southern Sweden. Copeia 1984: 707-713.
Meek, R. 2009. Patterns of reptile road-kills in the Vendée region of western France. Herpetological Journal 19: 135-142.

Meek, R. 2013. Post hibernation movements in an aspic viper, Vipera aspis. Herpetological Bulletin 125: 22-24.

Meek, R. 2015. Where do snakes cross roads? Habitat associated road crossings and mortalities in a fragmented landscape in western France. Herpetological Journal 25: 15-19.

Meek, R. 2016. Movements, mating and parturition in a female aspic viper, Vipera aspis, in western France. Herpetological Bulletin 137: 29-31.

Rugiero, L., L. Vignoli, L. Luiselli, and R. Meek. 2018. Spring basking by Vipera aspis: Observations from Italy and France on the displacement distances of basking vipers from their hibernacula. Herpetological Bulletin 145: 22-27.

Shine, R., M. Lemaster, M. Wall, T. Langkilde, and R. Mason. 2004. Why did the snake cross the road? Effects of roads on movement and location of mates by garter snakes (Thamnophis sirtalis parietalis). Ecology and Society 9(1): 9 <http://www.ecologyandsociety.org/vol9/iss1/art9>.

Speybroeck, J., W. Beukema, B. Bok, and J. Van Der Voort. 2016. Field Guide to the Amphibians and Reptiles of Britain and Europe. Bloomsbury Publishing, London, UK. 